\title{
Integrality from the perspective of nurses in the Family Health Strategy
}

Fabiana da Penha Colimoide ${ }^{1}$, Maria Dyrce Dias Meira ${ }^{2}$, Gina Andrade Abdala ${ }^{3}$, Sarah Lidiane Santos da Silva Oliveira ${ }^{4}$

\begin{abstract}
The aim of the present study was to understand the perception of nurses regarding the integrality of human beings in the practice of nursing care provided through the Family Health Strategy. An exploratory and descriptive study with a qualitative approach based on the Theory of Social Representation was carried out. A convenience sample of 29 nurses from a Regional Family Health Strategy was interviewed between June and September 2015. The transcript content was coded and analyzed based on the Collective Subject Discourse technique. The respondents revealed a clear perception of the importance of integrality in nursing care and understood that attending to and viewing people based on their individual characteristics will translate this perception. In order to achieve integral care within the therapeutic plan, certain external conditions are required, involving the synchronized performance of a multidisciplinary team acting within the macrostructure of the system, which translates into Health Care Networks.
\end{abstract}

Keywords: Integrality in health. Comprehensive health care. Nursing care. Health promotion.

\section{Resumo}

\section{Integralidade na perspectiva de enfermeiros da Estratégia Saúde da Família}

Este estudo objetivou conhecer a percepção de enfermeiros sobre a integralidade do ser humano na prática do cuidado de enfermagem no contexto da Estratégia Saúde da Família. Trata-se de pesquisa exploratória, descritiva, de abordagem qualitativa, fundamentada na Teoria da Representação Social, com amostra de conveniência composta por 29 enfermeiros de uma Regional da Estratégia Saúde da Família entrevistados entre junho e setembro de 2015. O conteúdo transcrito foi codificado e analisado com base na técnica do discurso do sujeito coletivo. Os entrevistados demonstraram clara percepção da importância da integralidade para o cuidado de enfermagem, ou seja, atender e ver o indivíduo como um todo, contemplando suas particularidades. Para que a assistência integral seja realizada no plano terapêutico são necessárias condições externas, envolvendo a atuação sincrônica da equipe multiprofissional com a macroestrutura do sistema, que se traduz em Redes de Atenção à Saúde. Palavras-chave: Integralidade em saúde. Assistência integral à saúde. Cuidados de enfermagem. Promoção da saúde.

\section{Resumen}

\section{Integralidad en la perspectiva de enfermeros de la Estrategia Salud de la Familia}

El objetivo de este estudio fue conocer la percepción de enfermeros sobre la integralidad del ser humano en la práctica del cuidado de enfermería en el contexto de la Estrategia Salud de la Familia. Se trata de una investigación exploratoria, descriptiva, con un abordaje cualitativo, fundamentada en la Teoría de la Representación Social, con una muestra de conveniencia compuesta por 29 enfermeros de una Regional de la Estrategia de Salud de la Familia, entrevistados entre junio y septiembre de 2015. El contenido transcripto fue codificado y analizado en base a la técnica del discurso del sujeto colectivo. Los entrevistados demostraron una clara percepción de la importancia de la integralidad para el cuidado de enfermería, es decir, atender y ver al individuo como un todo, contemplando sus particularidades. Para que la asistencia integral se lleve a cabo en el plano terapéutico se necesitan condiciones externas que involucran la actuación sincrónica del equipo multiprofesional con la macroestructura del sistema, que se traduce en Redes de Atención de la Salud.

Palabras clave: Integralidad en salud. Atención integral de salud. Atención de enfermería. Promoción de la salud.

Aprovação CEP-SMS CAAE 28905914.3.0000.5377

1. Mestre fabianacolimoide@gmail.com - Centro Universitário Adventista de São Paulo (Unasp) 2. Doutora dyrcem@yahoo.com - Unasp 3. Doutora ginabdala@gmail.com - Unasp 4. Mestranda sarah.oliveira@ucb.org.br - Unasp, São Paulo/SP, Brasil.

Correspondência

Fabiana da Penha Colimoide - Rua Galvão Bueno, 875, apt. 206, Liberdade CEP 01506-000. São Paulo/SP, Brasil.

Declaram não haver conflito de interesse. 
Integrated health care has emerged as an issue of great interest to government and public authorities, both in terms of the economy of the process of care and the ensuing requirements of strategies that treat the health of the individual as a whole. The term "integrated health" emerged in a subtle manner as an objective of the Health Reform Movement, and has since become a guiding belief of the Sistema Único de Saúde (Unified Health System) (SUS). Despite this, the idea has not yet fully become a reality in the lives of many Brazilians, as prioritizing preventive activities without negatively affecting care has proved an arduous task, notably due to communication breakdowns among actions aimed at prevention and individual and collective care, not to mention the current fragility of tertiary care ${ }^{1}$.

The SUS was designed to provide integrated care and incorporates an expanded concept of health resulting from lifestyles, organization and production in a particular historical, social and cultural context, seeking to overcome the concept of health as the absence of disease ${ }^{2}$. It therefore demystifies the centrality of biological factors as the only determinants of the disease process, and seeks to create actions aimed at integrated care.

In the context of the SUS, basic care (BC), or primary health care (PHC) as it is known around the world, represents a continuous line in the integrated care of individuals and aims to deal with all their health needs, injuries and diseases. PHC was first registered as a healthcare model in the 1920s in the Dawson Report in the UK. According to this report, health services should be provided in an organized and hierarchical manner, based in accordance with the level of complexity of the condition and demarcated by geographic region ${ }^{3}$.

$B C$ in Brazil is anchored in the Estratégia Saúde da Família (Family Health Strategy) (ESF) which was designed to meet the health needs of individuals in all their uniqueness and complexity, aiming at providing integrated or comprehensive care. It encourages the democratic participation of the user as an active presence to achieve resolutions of shared interests, as well as synchrony between community and individual, based on the common good and on respect for health needs in a community context, breaking through the fragmented formula of health care while remaining within the structures of the SUS ${ }^{3}$.

The change in the $B C$ managerial model allowed the emergence of the ESF as a model of quality care, achieved through systemic organization. This model strengthens the citizen-based ideology of its roots, according to which the state proposes a standard of health production based on coordinated care policies that are systematized and controlled through monitoring and the evaluation of the results and goals achieved. The care model should therefore result in de-hospitalization and preventive care ${ }^{4}$.

The biomedical model, predominantly based on specialization, is anchored in the idea that the individual can be treated in a fragmented manner, which results in mechanized care and undermines their role as a protagonist in the health-disease process. This strategy contrasts with the SUS proposal that guarantees integrated care to the user through treatment structured as the basis of a health promotion program ${ }^{5}$. The ESF has been structured to fulfill its primary purpose of reorganizing a new model of health care based on integrality, achieved through health promotion policies, based on the social determination of the health-disease process to understand and govern its proposals of action ${ }^{1}$.

In this context, it is necessary to align the educational model of training health professionals with the SUS proposals ${ }^{1}$. While there is still a long way to go, the National Curricular Guidelines (NCG) have made important contributions in organizing health care courses, especially in nursing. In addition to seeking to train generalist, critical-reflexive professionals capable of developing technicalscientific, ethical-political and socio-educational skills, the NCG suggest active methods for meaningful learning directed at critical-reflexive training. It is important to review the guidelines of health training to bring about structural change in healthcare.

Integrality in the promotion of health and in the field of care and care provision thus becomes a health production strategy in terms of the potentialities and specificities involved in creating therapeutic projects and organizing work and life through qualified interviews between users and staff. This not only ensures that sickness is not the only focus of attention, but also allows care to be accompanied by receiving, listening to stories and analyzing the life conditions of each individual ${ }^{2}$. This strategy does not see the patient as a fragmented system of diseases, and is able to view the user in an integrated manner, not only listening to their expressions of pain, but also sensing their real needs, which are often implicit.

Integrated care becomes the driving force for change in the biomedical model, reflecting the complex dimensions of human life ${ }^{3}$. It also aims to reduce the fragmentation of care and retrieve the right of the population to be cared for in terms of all their health needs. It is incumbent upon the 
state to offer organized services for integrated care that are closely related to the understanding of the determinants of the health-disease process ${ }^{3}$. Care therefore becomes a political device for achieving integrated treatment, and is, in the SUS, one of the guiding principles that means the user is treated indivisibly, as a whole inserted in the community? The individual must be assisted in a horizontal and vertical manner in referral and counter-referral networks that ensure integrated care ${ }^{8}$.

The major challenge, it seems, is the consolidation of an integrated system, with the articulation of actions at a regional level to ensure qualified attention, with good care and administrative practices. From this perspective, it is fundamental to structure care through Health Care Networks ( $\mathrm{HCN})$, in which the health system provides integrated actions, contributing to user access and the continuity of care. Linked to this, HCN, as an organizational model, integrates a system of technical and management support that seeks to improve the SUS and employ the rational use of existing resources for the integrality of health care ${ }^{3}$.

The HCN should be understood from a perspective of potential, since, in addition to therapeutic and diagnostic support, they provide procedures employing varying degrees of technology and the integration of management systems, supporting care units ${ }^{3}$. In this context, care goes beyond technical actions when carrying out the necessary procedures, involving more than the theory studied during training. It has a direct relationship with learning in seeing the other with all their peculiarities and challenges to be shared. In nursing, this should be intrinsic, and part of the daily care process to achieve integrality.

Integrated care should be sustained and defended in the practice of health professionals, resulting in health care aimed at multiple organic, social, emotional and spiritual aspects, with the focus on the restoration and vitality of the human being ${ }^{7}$. Therefore, the training of health professionals, especially nurses, should include guidance that potentializes skills aimed at integrality, and be aimed at tackling the health needs of the population and the development of the health system itself ${ }^{9}$.

The health professionals' perception of integrated care emerges from programs such as Community Health Agents, Female Health, Health of the Elderly, Health of the Child, Health in School, Breast Feeding Brazil Network and Mental Health, among other working models, such as matrix-based strategies, group therapy and home visits. All these actions contribute to achieving integrality. However, despite the efforts of planning work based on the communication between patient and professional and between professionals themselves, integrated care is not yet a reality. The lack of interconnected work and shared responsibility in decisions and actions, following discussions of clinical cases, results in ineffective communication, which diminishes the importance of the needs of users ${ }^{10}$. As such, the aim of the present study was to identify the perception of nurses on the integrality of the human being in the practice of nursing care in the context of the ESF.

\section{Method}

An explorative, descriptive study with a qualitative approach was carried out. The survey described in the present article is part of a study of 29 of the 75 nurses that work in twelve ESF units located in the south of the city of São Paulo, Brazil. Data was collected between June and September 2015, and the criteria for selection was nurses working in ESF units at the time of data collection.

The study was performed through a semistructured interview, which was recorded and subsequently transcribed. Sociodemographic data such as age, training time and time spent working as a nurse were collected. The following guiding question was analyzed: "what do you understand by integrality in health care?". Nurses that agreed to participate in the study signed a free and informed consent form in accordance with the Declaration of Helsinki ${ }^{11}$ and CNS Resolution 466/2012 ${ }^{12}$.

The interviews were carried out during meetings organized by the administration of the regional ESF unit. The interviews were transcribed in their entirety and the discourses of the nurses, codified with the numbers of each nurse (N1, N2, N3...), were submitted to analysis using the Discourse of the Collective Subject (DCS) technique, which was used to construct a panel of the representations of the participants in the form of a singular discourse, with the retrieval of the collective thought. According to this technique, the essence of each statement is extracted based on excerpts described as "central ideas" (CI), made up of key expressions (KEX).

The representations on the theme studied are brought together in the sets of the discourses that make up the DCS and may subsidize questions and discussions about the motives through which people present their thoughts, their consequences 
and their practical implications ${ }^{13}$. Analysis of Discursive Content is based on the Theory of Social Representation ${ }^{14}$. As a presupposition of Sociology, it proposes that any emotion, belief, idea, religion, myth or science can be included as an object for analysis in the context of social representations. As such, this theory adds the results investigated to the possibility of greater understanding of the questions posed ${ }^{15}$.

\section{Results and discussion}

The sample of participants comprised 29 nurses, of whom three were men and 26 were women. In terms of sociodemographic profile, the age of the participants ranged from 24 to 57 years, with the greatest concentration between 24 and 30 years. Time spent working as a nurse ranged from six months to 33 years, and training time was predominantly up to ten years. The results of the interviews, categorized in the form of DCS, is presented in response to the first guiding question "what do you understand by integrality?" It is worth mentioning that the answers can be represented in more than one $\mathrm{Cl}$, that is, two responses that were taken from one participant were included in more than one DCS. There was therefore an increase in the number of responses $(n=30)$, as shown in Chart 1:

Graph 1. Absolute frequency of central ideas, according to key-expressions, in reference to the question "what do you understand by integrality in health care?"

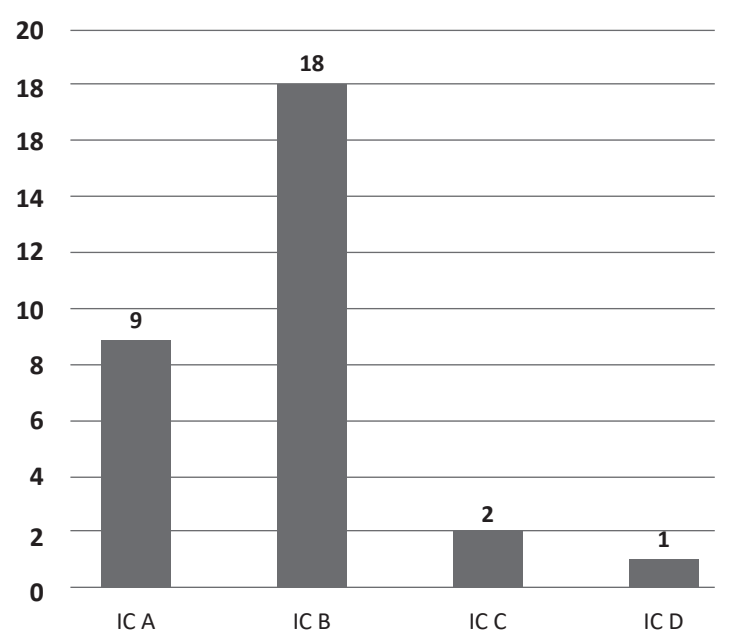

$\mathrm{Cl}$ A: seeing the individual as a whole; $\mathrm{Cl} B$ : providing care to the individual as a whole; $\mathrm{Cl} C$ : the performance of the multiprofessional team; $\mathrm{Cl} D$ : the need to structure the service to achieve integrality of care.
Central Idea A: seeing the individual as a whole (9 KEX)

DCS - "Integrality in health care is to understand the individual as a whole, in their various dimensions, not only the health problem they are suffering from, but also seeing it fully, in terms of mental, spiritual and physical health. That's what I understand. We look at the patient as a whole. We do not look at only the disease they have, but what makes up the individual."

"Integrality is seeing the patient, the person, the user as a whole, in all aspects of their lives, not only the physical, but also the mental, the way of dealing with life. It is a vision of the person as a whole, being a composition of mental, spiritual and physical well-being";

"The way you look at it differs from the way you provide care, because the individual is not merely a disease or an extra statistic in the health environment. They will be considered in a non-fragmented way, but in the integrality of receiving care".

Integrality is a value to be sustained as a principle in the daily practice of nurses, assuming that when encountering a patient, one seeks to overcome the biological view that reduces them to a fragment. This effort starts from the idea that reductionism refers to psychosocial suffering, and if it is to be avoided, the patient must be seen as an integral being. Thus, the possibilities for disease and suffering are converted into a resilient and less difficult process than the one currently employed, since the focus is not only on the disease, but in the context in which it was caused and in which the patient is inserted ${ }^{7}$.

It is assumed that nurses have already incorporated the capacity for the humanized reception of patients into their working practice, as well as the interactive and associative ability to understand the human being as a whole, contemplating the integrality of health care in the treatment provided in their daily life and work processes ${ }^{16}$.

Central Idea B: providing care to the individual as a whole (18 KEX)

DCS - "It is providing care to individuals in their totality, which is integral care, and not just seeing the specific disease, but providing all the necessary means for the health of the person in the community, with physical, spiritual and moral wellbeing, the whole approach of and to the patient"; 
"It is the care of the patient as a whole, with prevention and health promotion, evaluating every aspect of the person, every aspect of them, including the psychological, providing the service is appropriate to the user's need in an integral way. Do for them what they require, promoting complete care, in everything that the patient needs, in all aspects".

Integrated health care has non-negotiable presuppositions that should not be overlooked, given that integral care is a constitutionally guaranteed right for each individual in the completeness of such care. In aiming for completeness, every individual should be seen and should receive care as a complete and not fragmented being. This principle represents the centrality of health practices so that the needs of the population are met $^{5}$.

According to the interviewees, it is vital to assist the individual as a whole and not to provide them with fragmented care. The idea of integrality seems to overlap with the Cartesian paradigm, for in this conception the mind is part of the body and vice versa, and if one is affected, the other will also suffer. In this context, care is understood as the set of behaviors and actions that involve knowledge, attitudes, skills, intuition and critical thinking in relation to being cared for, in order to promote, maintain and/or recover both health and human dignity and totality ${ }^{17}$.

\section{Central Idea C: it is the performance of the multiprofessional team (2 KEX)}

DCS - "It is group work involving the entire multiprofessional team. The patient enters primary care requesting help or needing something. Then, in the health service, from the moment he enters, at the first conversation the process of integrality begins. He will need the care and monitoring of a teame".

The participants of this study translated the responsibility of the team to mean that the care for the patient goes beyond the formality of treatment provided only by the nursing staff. To achieve integrality, one cannot imagine that care is the responsibility of only one professional or health service. The principles should be networking, listening to personal needs, socially responsible ties with the population, and the adoption of resolutive measures by all who make up the health team ${ }^{18}$.
It is up to all the professionals in the treatment site to create a continuous network of care so that the patient feels cared for in an integral manner. Government, which creates management and training policies as well as professional training, can contribute to better care which values the process of caring ${ }^{8}$. Integrated work among professionals and other sectors is increasingly necessary when faced with the demand for complex care, in which interdisciplinary discussions contribute to the effectiveness of comprehensive work aimed at integral care ${ }^{9}$.

Central Idea D: the need to structure the service to achieve integrality of care (1 KEX)

DCS - "It means having a structured service in which the therapeutic plan, which I can offer him [the patient], is within the possibilities that the service provides me with, so that I can help with all aspects of his needs - physical, mental and spiritual."

Sectoral structuring for nurses and other professionals when performing care is relevant and necessary, according to the discourse of the participants. The possibility of integral care is linked to the minimum conditions to execute the therapeutic plan, as described. State health departments are responsible for implementing National Policies for Health Promotion, which support and promote the implementation of programs, plans, projects and actions related to the promotion of health, taking into account the epidemiological profile and the needs of its territory ${ }^{19}$. The importance of consolidating integrality in health services is therefore emphasized, assessing and supplying the needs of the environment and the profile of the population receiving care ${ }^{17}$.

In addition to the institutional aspect, there is also individual responsibility, in that the attitude of the health professional can make a difference to achieving integrated care. The representation of the participants leads us to question whether the proposals presented in public health policies are a reality in daily life. The DCS presented in $\mathrm{Cl} C$ considers qualified and sensitive listening to be an initiative of professionals themselves, implying that it is not directly dependent on organizational structure.

According to the discourse of the participants, qualified listening is an action that enables individuals to feel they are receiving integrated care, suggesting that it should always be associated with other professional attitudes. In particular, the nurses 
who normally receive the individual at reception can contribute to this so that, in the continuity of care, the information collected during such a listening process can be used to plan health care aimed at the integrality of the human being.

\section{Final considerations}

The concept of integrality was widespread among the nurses who participated in the study, as they recognized that for full and complete health care people need to receive integrated treatment for all their characteristics and individualities. However, the results of the study lead us to question whether the practice is as manifest as is the awareness of it. For the participants, health care involves caring for the physical, mental, psychological and spiritual aspects of the individual. However, they revealed in their discourse that integrality should not only be the focus of their work, but should extend to the entire multiprofessional team. This would allow integrated care to begin during the individual's first contact with the ESF health professionals, so creating a humanized service with qualified, guided listening from the outset.

The ideal treatment plan, according to the interviewees, requires suitable external conditions if it is to be implemented successfully, implying the need for government intervention so that integrated care becomes a reality when addressing the individual needs of the clients. Integrality should be emphasized within management visions and goals so that it becomes a daily practice in ESF. It was concluded that the perception of nurses regarding the integrality of the individual in the practice of nursing care was broad, and was suggestive of a reassessment of actions aimed at integrated care for the individual in the context of the EFS. They also suggested that integrality should not be limited by external conditions, but should be directed by conduct based on the personal and interpersonal ethics of professionals in relation to the patient, although the influence of the political spheres is theoretically preponderant.

Seeing and caring for the individual as a whole were perceived as important by the respondents, which is a pre-requisite for integrated care. It was also found that the actions of nurses need to be more pragmatic, involving attitudes that go beyond the theory and protocols instituted in the context of the ESF. From this perspective, it can be perceived that integrality in health requires the synchronous performance of the multiprofessional team, anchored in a systemic vision and connected to the macrostructure, which in turn must be organized within the HCN. The challenge is to concretize such working structures within health networks that aim to establish a practice of care which treats individuals in an integrated manner, something that is not yet a reality.

\section{Referências}

1. Fracolli LA, Zoboli ELP, Granja GF, Ermel RC. Conceito e prática da integralidade na atenção básica: a percepção das enfermeiras. [Internet]. Rev Esc Enferm USP. 2011 [acesso 7 set 2016];45(5):113541. Disponível: http://bit.ly/2wG2gUN

2. Brasil. Ministério da Saúde. Política nacional de promoção da saúde: PNaPS: revisão da Portaria MS/GM no 687, de 30 de março de 2006. Brasília: Ministério da Saúde; 2014. p. 7.

3. Lavras $\mathrm{C}$. Atenção primária à saúde e a organização de redes regionais de atenção à saúde no Brasil. [Internet]. Saúde Soc. 2011 [acesso 12 Jun 2017];20(4):867-74. Disponível: http://ref. scielo.org/d467zt

4. Melo RC, Machado ME. Coordenação de unidades de saúde da família por enfermeiros: desafios e potencialidades. [Internet]. Rev Gaúcha Enferm. 2013 [acesso 18 set 2016];34(4):61-7. Disponível: http://bit.ly/2w6uAMi

5. Seixas CT, Merhy EE, Baduy RS, Slomp Junior H. La integralidad desde la perspectiva del cuidado en salud: una experiencia del Sistema Único de Salud en Brasil. [Internet]. Salud Colect. 2016 [acesso 18 set 2016];12(1):113-23. p. 117. Disponível: http://bit.ly/2w6QCPe

6. Vieira MA, Souto LES, Souza SM, Lima CA, Ohara CVS, Domenico EBL. Diretrizes Curriculares Nacionais para a área da enfermagem: o papel das competências na formação do enfermeiro. Renome. 2016;5(1):105-21.

7. Teixeira GB, Silva CA, Teixeira LB, Monteiro Al. Compreendendo o princípio da integralidade na visão de discentes da graduação em enfermagem. Esc Anna Nery. 2013;17(4):764-71.

8. Lima IFS, Lobo FS, Acioli KLBO, Aguiar ZN. Integralidade na percepção dos trabalhadores de uma unidade básica de saúde da família. Rev Esc Enferm USP. 2012;46(4):944-52.

9. Oliveira IC, Cutolo LRA. Percepção dos alunos dos cursos de graduação na saúde sobre integralidade. Rev Bras Educ Méd. 2015;39(2):208-17. 
10. Andrade SR, Mello ALSF, Locks MTR, Mattia D, Hoeller F, Erdmann AL. Melhores práticas na atenção básica à saúde e os sentidos da integralidade. Esc Anna Nery. 2013;17(4):620-7.

11. World Medical Association. Declaration of Helsinki: ethical principles for medical research involving human subjects. [Internet]. Helsinki: WMA; 2000 [acesso 26 mar 2016]. Disponível: http://bit.ly/2rJdF3M

12. Brasil. Conselho Nacional de Saúde. Resolução CNS no 466, de 12 de dezembro de 2012. Aprova as diretrizes e normas regulamentadoras de pesquisas envolvendo seres humanos. Diário Oficial da União. Brasília; jun 2013. Seção 1.

13. Figueiredo MZA, Chiari BM, Goulart BNG. Discurso do sujeito coletivo: uma breve introdução à ferramenta de pesquisa qualiquantitativa. Distúrb Comun. 2013;25(1):129-36.

14. Durkheim É. As regras do método sociológico. 14a ed. São Paulo: Nacional; 1990.

15. Moscovici S. Representações sociais: investigações em psicologia social. 6ạ ed. Petrópolis: Vozes; 2009.

16. Backes DS, Backes MS, Erdmann AL, Büscher A, Maya AMS. Significado da prática social do enfermeiro com e a partir do Sistema Único de Saúde brasileiro. Aquichan. 2014;14(4):560-70.

17. Viegas SMF, Penna CMM. As dimensões da integralidade no cuidado em saúde no cotidiano da Estratégia Saúde da Família no Vale do Jequitinhonha, MG, Brasil. Interface Comun Saúde Educ. 2015;19(55):1089-100.

18. Porto D, Schierholt SR, Costa AM. Retratos da relação médico-paciente na atenção básica. Rev. bioét. (Impr.). 2012;20(2):288-99.

19. Brasil. Ministério da Saúde. Op. cit. p. 26.

\section{Participation of the authors}

Fabiana da Penha Colimoide participated in the planning of the study, the analysis and interpretation of data, the writing and the formatting of the manuscript. Maria Dyrce Dias Meira and Gina Andrade Abdala contributed to the planning, analysis and interpretation of data and critical review. Sarah Lidiane Santos da Silva Oliveira collaborated in the formatting and critical revision of the manuscript. All the authors cooperated in the approval of the final wording.

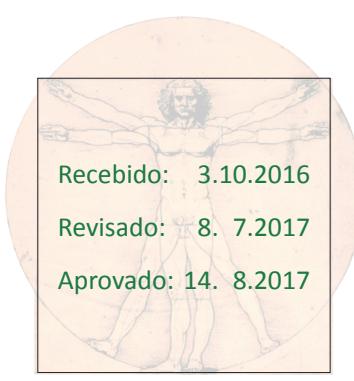

